\title{
Political Uses of History in Spain
}

\author{
PEDRO RUIZ TORRES
}

Politics has always been closely bound up with history, which in turn has often been used for political purposes.' History is currently playing an important political role in many different societies. Where the shaping of a national identity remains a problem or where old conflicts still linger, setting peoples or nations against one another, it occupies the centre of political debate and serves to justify a wide variety of actions and opinions. But even where there are no such problems, history is strengthening its ties with politics. Historians, or at least some of them, are beginning to become known for their repeated appearance in the media when it comes to matters of internal or international politics. A considerable number of history hooks and memoirs and publications of a popularizing nature reveal clear political motivation, not to mention the debates that they provoke. But it is undoubtedly in commemorations that the increasing politicization of history is seen most clearly. Historical commemorations sponsored hy a wide range of governments follow hard on each other's heels.

In Spain, 1998 was the year of commemorations par excellence, just as 1995 had been in the countries that celebrated the fiftieth anniversary of the end of World War II. Spain had not taken part in that war - although the then recently established dictatorship of Franco had shown that it favoured Nazi Germany and Mussolini's regime - and was therefore in no position to recall the defeat of fascism, but in 1998 it was faced with a very special occasion. Several commemorations coincided that year. The first was the centenary of Spain's military defeat at the hands of the United States in the Spanish-American War, which brought about the loss of the last remnants of the colonial empire in America and the Pacific islands. In 1898 that empire disappeared completely, plunging Spain into a 'decline' against which a reaction came from a group of intellectuals the so-called Generation of ' 98 - who were highly critical of the political system of the monarchy of the time. This was in a way an awkward, inopportune commemoration for the current rulers, but in the same year another commemoration came to their aid: the quarter centenary of the end of the extremely long reign of Philip II, the king who raised the Spanish empire to its highest point in Europe and America. Also in 1998, the democratic constitution that governs the current political system 
celebrated its twentieth anniversary, something without precedent in the entire history of Spain.

These are not the only historical dates to have been specially commemorated in Spain during the past decade. Going back to the Socialist period, in 1988 there was the celebration of the bicentenary of the death of Charles III, a moment used for official exaltation of the reformist work of the very moderate enlightened Spaniards, contrasting with the slight interest aroused a year later by the bicentenary of the French Revolution. In the same year, 1988, the nationalist autonomous government of Catalonia promoted the celebration of the "millennium of the Catalan nation', and in 1992 it placed special emphasis on the centenary of the Bases de Manresa, represented as the origin of modern political Catalanism. None of those events came anywhere near achieving the impact of the great commemoration par excellence, the quincentenary of the 'discovery' of America, promoted in this case by the national government at the height of the Socialist era. In the 1990s there were also commemorations of less substance and without much official support which did not penetrate deeply into public opinion but served to recall, for example, the figure of the dictator Franco 100 years after his birth (1992), and the completion of 20 years since the beginning of the transition to democracy (1995) and 60 years since the start of the Civil War (1996). In 1997, with the right-wing government of the Popular Party having recently assumed power, official interest in historical commemorations became apparent once again. The reason that year was the centenary of the assassination of the Conservative leader Antonio Cánovas del Castillo, the architect in 1874 of the restoration of the monarchy and the consolidation in Spain of a moderately liberal parliamentary regime that, nevertheless, subsequently proved incapable of evolving towards true democracy. Immediately afterwards came 1998 , as noted, and the commemoration of the 100 years since the colonial 'disaster' and 400 years since Philip II's death.

The commemorations just mentioned are examples of a new kind of political use of history. Today the myths cultivated by national/Catholic fundamentalism have become things of the past, as has the ideological combat that conditioned the development of Spanish historiography for most of the twentieth century. The new political uses of history are of a different kind. Most often they have the support of historians and an academic backing that makes them professionally 'respectable'. Criticisms of the motivation for these institutional initiatives rarely achieve public notice. The installation of democracy led to a weakening of the old myths and great ideologies against the background of which a tradition of 'scientific history' had laboriously been created. Politically committed 
academic activity began to be abandoned, and most professional historians attached a high value to the cultivation of aseptic monographs and professional debate among specialists as natural elements of their work. In many cases this attitude then became compatible with an evident sense of pleasure in initiatives of an institutional nature that presented the appearance of 'scientific professionalism'. The social impact of these initiatives conferred on history a usefulness all the more appreciable as the weight of the old discipline in our current educational system diminished. At the same time, history increasingly became a target of political exploitation, although in a new way.

The politics of history in Spain at present cannot simply be reduced to the conntry's intense involvement in official commemorations during the past decade. In a quite different context we must also refer to the role played by legal proceedings of international scope such as those that elucidated the participation of Franco's government and certain Spaniards close to it in the plundering of Jews during World War II, or magistrate Baltasar Garzón's action against Pinochet for his responsibility in connection with the torture and murder of Spanish citizens, among others, in Chile after the military coup against Salvador Allende's democratic government. There has also been a very significant response in the media to certain polemics, such as those focusing on the nature of the Franco regime and its similarities and differences with respect to fascism, ${ }^{2}$ the pros and cons of a transition not as exemplary as we had been led to believe, ${ }^{3}$ and, recently, the controversy over the role of certain outstanding intellectuals in the 1940s, supporters of the dictatorship at the time and later outstanding points of reference in the opposition to it. The educational function of history has become the subject of intense political debate, ${ }^{5}$ and two university events have evoked politically uncomfortable memories: the reception and tribute given to survivors of the International Brigades in the auditorium of the University of Valencia and the conference on the Maquis (the Republican guerrilla forces that continued armed resistance against Franco's dictatorship after the end of the Civil War) also organized within that university.

The political role currently played by history in Spain is not comparable to the part it played in the time of Franco's dictatorship, but equally it contrasts with the silence and forgetfulness promoted during the transition to democracy by political means (parties, government) and for political purposes (to help to bring about a peaceful transition from dictatorship to democracy after Franco's death in 1975). The desire to achieve a peaceful solution supported by a broad consensus made certain questions about the past awkward. The political climate of the late 1970 s and early $1980 \mathrm{~s}$ tended to favour forgetfulness with the aim of encouraging concord and 
reconciliation among Spaniards. The transition to democracy was accompanied by fear of remembering the immediate past; the future counted more than a history full of failures which some might use as weapons against others. Directly or indirectly, the great catastrophe of the Civil War continued to weigh upon the conscience of most Spaniards. However, as democracy became established and the intensity of the changes turned Spaniards away from fratricidal conflict and as those who had lived through the Civil War moved out of the public eye or disappeared, the amnesia ceased to have the political meaning conferred upon it by the 'agreed-upon' transition to democracy. In the new atmosphere of the late 1990s we begin to see signs of a personal and collective need to recover the past in a different way, far removed from the commonplaces promoted by the old ideologies and from the oblivion that falsely closed the wounds of the past during the transition.

\section{THE POLITICS OF HISTORY AND NATIONAL IDENTITY}

Of all collective identities, national identity is by far the one that has predominated in the past two centuries. A certain tradition of memory and history crystallized around the nation as a new hegemonic collective identity. The France of the Third Republic is the supreme example of the process of constructing a tradition of memory (les lieux de mémoire) and a science of history that remained in the hands of professionals specialized in its study and convinced that they were employing the 'scientific method' and had the ability to convert documents into 'objective evidence' derived from the past. The use of that tradition of memory and science of history for political ends (to legitimize, unite, and perpetuate the nation-state) and the close link between it and nationalist ideology have been pointed out on numerous occasions. However, there are other aspects of the relationship between politics, memory, and history that deserve to be taken into consideration and that arise only when the frame of reference is not the process of bnilding a strong hegemonic national identity at the prompting of the state, in the style of France, but the manifest weakness of the state when that objective has been achieved.

Spain is different from other Mediterranean countries in a number of ways. The use of history has also played a fundamental political role here in ideological conflicts, especially in the conflict that arises from the construction of a 'state-centred' national identity. At the heart of that process and with that conflict as a setting, memory and history have been used in an uncritical, simplistic way for purposes of ideological propaganda. In Spain as in France and Portugal, the modern state goes back to a very early date, and therefore in the origins of this state both history and politics 
were subordinated to the interests of certain social sectors and corporations with their particular privileges. The modern state arose in Spain, as in France and Portugal, long before the existence of a public sphere favourable for the exercise of politics as we understand it now or of a specific professional environment for the cultivation of history. It was, therefore, a state that preceded nationalist ideology, a state that over several centuries acquired modern features which did not, however, include considering the imposition of a national identity. What is characteristic of Spain, however, is that the state sought to legitimize itself through an ideology, that of the Catholic empire, which, while not yet strictly nationalist, was later able to evolve towards a kind of nationalism that has left a long, deep mark on our contemporary history.

Two further characteristics are provided by the fact that during the period of nationalisms Spain, in contrast to France, lacked a strong, incontrovertible national identity and a history to support it in a professional, 'scientific' way. ${ }^{6}$ Throughout the twentieth century the weak establishment in Spain of that identity and that type of history was linked with the emergence of two kinds of conflict: conflict between various conceptions of Spanish national identity, which prevented the development of a hegemonic national consciousness, and conflict between those who supported a Spanish identity and those within the state who rejected that identity and defended the constructions of national identities other than the Spanish. These conflicting identities created their own images of the past and advocated different kinds of history.

As a result, no strong hegemonic tradition of a nation-state variety of memory/history emerged in Spain. History that identifies nation with state and provides them with a common nation-state-centred identity recognized as belonging to them by most citizens - the 'classical' or 'traditional' history capable of forming or reinforcing a national consciousness that coincides with the territorial limits of the state - has had little social influence. Still less, therefore, have there been the conditions necessary for using that memory/history to create a national critical history, the kind of history that Pierre Nora has proposed in France, starting from the concept of lieux de mémoire $e^{7}$ and seeking to adapt national history to the new scientific and civic needs of our time. The odd study on 'places of memory' can be found in Spain, ${ }^{\circ}$ but the country lacks a tradition capable of establishing itself in the academic world and in public opinion in such a way as either to maintain interest in a traditional kind of national history or to propose a new national history setting out from the alternative proposal of lieux de mémoire.

That there is no strong hegemonic tradition of a nation-state variety of memory/history in Spain at present can be verified in three ways. First, 
during the past three decades the history of Spain has gradually been displaced by history concerned with subjects other than the nation-state such as stateless nations and regions (the 'autonomous communities'), small societies of a local nature (rural or urban), or social groups (social classes, professional groups, women). The recent reaction to this abandonment of the history of Spain is eloquent in this connection. Some recently published histories of Spain (those of García de Cortázar and Tusell $)^{9}$ must be placed in this context, but their relative success in publishing terms must by no means be understood as a trend. Second, the recent 'debate on the humanities' has highlighted a profound divergence among the various public authorities with responsibilities for education (central government and autonomous governments), between public authorities and historians, and even among historians." This conflict, which has attracted public attention, is indicative of the current complete lack of agreement about the kind of history that should be taught in Spain.

Third, there is the polemic nurtured by the various party leaders and certain groups of intellectuals with a strong influence on public opinion because of their frequent appearances in the media - about whether the democratic state is authorized to promote a nationalization of collective memory and of history. The fact that there is discussion about whether such a nationalization makes sense nowadays and how it should be carried out (whether in favour of a predominantly Spanish national identity or of recognition of the various national identities on an equal footing, where the plurality of national entities should lead, and so on) shows a total lack of political consensus. On the one hand there are those who support reinforcing Spanish national identity and for that purpose recovering the history of Spain while at the same time promoting the nationalization of memory and history as classically conceived. On the other hand, there are those who reject the idea that the 'state of autonomous regions' should even consider such a possibility, since it would favour the cultural and political standardization characteristic of the past in the face of the tendency towards plurality and decentralization of our time. The former complain of the absence of a memory and history of the Spanish nation that might provide a solid basis for awareness of a common identity extending to all inhabitants of the state. The latter criticize the attempt to use history to legitimize state-centred nationalism and advocate the creation of new collective identities, both supranational (a united Europe) and subnational (cities, regions, former stateless nations).

To use a musical metaphor borrowed from Jeffrey Olick, "it seems as if, after a long period during which the homophony of the eschatology of the church persisted, only relatively recently to disappear, modern Spain has 
fully entered the polytonality of multiculturalism without having known, other than briefly and always imperfectly and controversially, the polyphony of national state ownership.'2

\section{TWO POLITICALLY OPPOSED KINDS OF HISTORY}

The fact that Spain lacks a strong, deeply rooted tradition of memory/history of the kind that we find in nation-states in the West is clearly due to a variety of factors that could equally account for the much discussed weakness of the nation/state in our country. ${ }^{13}$ As far as the constitution of that tradition is directly concerned, in twentieth century Spain there were two almost opposite ways of representing the past and the process or path traced in it. ${ }^{14}$ Those two conflicting global views of our history were uourished by the clash between two ideologies that disputed political hegemony throughout the nineteenth century and the better part of the twentieth. The deep ideological and political fracture of Spain that gave rise to those two traditions of historical memory goes back to the point when the ancien régime went into a crisis and the liberal revolution made its appearance. Since then the conflict, sometimes latent and sometimes manifest in the form of successive civil wars, has been reproduced equally in the view of the past and in the use of history as a basis for national identities in the new state. Two opposed views of the history of Spain - one here called 'orthodox' because of its traditional nature and another in tune with liberal thinking - confronted one another without either managing to achieve clear dominion for most of the twentieth century.

The 'orthodox' view has its roots in the religious and state-centred conception that emerged at the time of the Catholic empire, when the Spanish monarchy expanded in Europe and created a huge colonial empire in America. This conception of history had the implicit consent of the new state, which, despite its formally liberal nature, left primary education in the hands of the Catholic Church. Later, during the twentieth century, 'orthodox' history had the support of two dictatorships (the dictatorship of Primo de Rivera, between 1923 and 1930, and the dictatorship of Franco, betweeu 1939 and 1975, the latter with totalitarian pretensions), and it was very much present in schools until at least the 1960s.

The 'orthodox' history of Spain is a simple Manichean account of historical events enacted by heroes and martyrs of the national/Catholic cause. Without a break, the thread of that history links the prehistoric origins of the 'beloved country' (the moment when the Celtiberians, with their 'simple customs' and 'independent nature', brought about the emergence of the 'true Spanish race') to the 'miracle' of the introduction 
of Christianity (thanks to St James the Apostle and the intervention of the Virgin of the Pillar), the constitution of the Visigothic Catholic monarchy (which united the Peninsula for the first time), and the advance of the Reconquest during the Middle Ages (which finally succeeded in expelling the invaders who supported the 'false prophet Mohammed'). Seen in this way, the history of Spain culminates in the glorious reign of the Catholic monarchs with the definitive religions and political unification of the country, the creation of the 'Holy Tribunal of the Inquisition', which succeeded in preserving national/Catholic unity, and the 'discovery' of America, opening up the new continent to Hispanic evangelization. Later there is the pinnacle of the Christian empire during the reigns of Charles $\mathrm{V}$ and Philip II and the increasing decline as rulers moved away from the designs of divine providence, gave up the traditional spirituality promoted by the Catholic Church, and fell into the hands of 'materialistic and foreign' ideologies alien to the 'true nature' - spiritual and national - of the Spanish people.

This interpretation of history, which set out to explain the greatness and decline of Spain in accordance with its adherence to church and monarchy, preserved a distinctly traditional, antimodern character derived from the old counter-Reformation ideology from the time of the empire. With a few significant modifications it was able to adapt to the new middle-class society and (especially in the rural Spain that continued to predominate until the mid-nineteenth century) counteract the political advances of liberalism. Thanks to the predominant role of the Catholic Church in primary education, this kind of history was very much a part of the education of Spaniards until the last third of the twentieth century. ${ }^{15}$

Later, the Franco regime used the national/Catholic view of the history of Spain and the tradition of memory that it provided (St James the Apostle, Covadonga and Pelayo, el Cid, the Catholic Monarchs, Hispanidad) to legitimize a national/militarist ideology and a theocratic/charismatic conception of the state that was fittingly personified by the figure of the Caudillo or 'Leader'. The Caudillo, having won the war, thereby became the one chosen by divine providence to rescue Spain from its decline and lead it along the path to the imperial glory of bygone years. In this way, with the sole but important modification that militarist caudillismo introduced in occupying the position of the monarchy, vacant since the victory of the Second Republic, during Franco's era the history of Spain officially continued to correspond to the same divine plan that had long before been 'revealed' by national/Catholic ideology and historiography.

According to this view of the past, the Spanish people, who had been chosen by divine providence, constantly displayed a national character in 
harmony with the spiritual values of the Catholic Church, values of which the army, triumphant in the Civil War of 1936-39, was now the main guarantor. All this provided a basis for the indissoluble unity of Spain and gave meaning to the struggle against any kind of 'invasion, heresy, separatist tendency and pernicious lay ideology, anti-Spanish by nature', among which freemasonry, liberalism, and communism were prominent. When Spain had good rulers whose desire was not to imitate other nations but 'to maintain the virtues of the race' and 'to follow the designs of God', it attained its 'supreme imperial greatness'. ${ }^{\text {t6 }}$

This religious fundamentalist conception of the history of Spain obviously had an ideological basis with traditional, antimodern leanings that its promoters at no point sought to hide. With such an ideology there was little need for the research work of professional historians, work that at the beginning of the twentieth century was barely established academically in Spain, in contrast to France or Germany, and that hardly began to be developed during the first third of that century. For the national/Catholic representation of the past to adorn itself with a certain intellectual air it was sufficient to refer to the work of prestigious Catholic philosophers of the nineteenth century such as Donoso Cortés y Balmes or to fall back on the most reactionary ideas of the early Menéndez y Pelayo.

To combat sucb a view of the past it was not sufficient for a different kind of history to emerge in the academic world. It was undoubtedly important that in some classes in secondary education institutes and universities at the end of the nineteenth century a history appeared that was conceived as a positive science ready to dismantle reactionary myths and criticize the manipulation of the past. But challenging the traditional ideology required an alternative global view, and for this purpose, in addition to the scientific conception of history, literature with a historical content and especially the new literary genre of the historical novel proved enormously useful. ${ }^{17}$

The liberal view of the history of Spain was much more in accord with the modern nationalist spirit that was developing in the more advanced states in Europe, but it was limited with regard to its development in universities and its diffusion in society. Following the lines of liberal ideology, the course of history now became a permanent setting for the struggle of the Spanish people against political or religious tyranny. Without relinquishing the idea of the very ancient origins of the Spanish nation, liberal criticism focused on the end of the Visigothic monarchy (because it was a theocratic one) and the times of religious intolerance, especially during the era of Philip II. The Middle Ages were positively evaluated in terms of the limitations on monarchic power imposed by the Spanish parliament and municipalities in the Christian kingdoms and the 
religious tolerance that, despite the war, existed on both sides during the Reconquest. The particular characteristic of Spain, it was even said, was the coexistence of Christians, Moors, and Jews in the Middle Ages, despite the conflicts that it caused. In modern times there was a special attraction in attempts to set limits to authoritarian power, as happened during the revolts of the Comunidades in Castile and the Germanias in Valencia. The enlightened reformism of Charles III's reign, in the mideighteenth century, was presented as the heginning of a truly Spanish revolntion, subsequently cut short hy the shameful reign of Charles IV and the Napoleonic invasion.

After a nineteenth century of constant civil wars and conflicts that prevented the occurrence of the revolution that the country needed, a new stage seemed to commence at the start of the twentieth century with prospects of the 'regeneration' of Spain. The material and intellectual progress of the Spanish people depended on the success of that revolution, which quite clearly was to be one promoted from above and aided by the enlightened classes, thus avoiding the violent outbreak of mass discontent that was perceived as an imminent danger. This view of history was bound up with a plan of transformation that set its sight on modern developed Europe and considered the old traditional Spain, the Spain that officially professed to he Catholic, an encumbrance from the past. Similarly, in the opinion of the more advanced liberals, political unity could be preserved only by the concession of a greater degree of freedom, so that the different peoples of which Spain consisted could be provided with their own governments (either from a radical perspective, disposed to refound the state, as defended by republican federalists with scant success, or else from a different perspective, much more moderate in tone and autonomist and regionalist in style). It was a further lesson provided by the liberal, lay, progressive history that in different periods of our development a common popular democratic demand for decentralization and self-government resisted the repression exercised by authoritarian powers.

This liberal, nationalist conception of the history of Spain, contrasting with the tradition of memory promoted by the national-Catholic view, had its moment of victory, albeit short-lived, during the Second Republic (in the historiographic renovation whose most outstanding figure was Rafael Altamira). ${ }^{18}$ Subsequently, from 1939 onwards, it had to seek refuge in exile or in secrecy as the winners of the war imposed an almost complete disregard of those ideas until Franco's dictatorship began to tolerate a certain sort of dissidence in the late 1950s. 
THE END OF THE DICTATORSHIP AND THE TRANSITION TO DEMOCRACY

In the final stage of the dictatorship the out-and-out supporters of the Franco regime continued, with more or less scholarly rigour according to their level of education and intellectual stature, to defend a traditional, 'orthodox' history of Spain, repeating the clichés of hispanidad and identification with Catholicism, the unity of the nation since remote times, the Christian empire that had been succeeded by a decline due to bad rulers, and criticism of the enlightened reformism, liberalism, and socialism that had been imported from abroad. In addition to all this there was now a special interest in the figure of Ferdinand VII, the king who, between 1815 and 1833, sought to preserve the traditional order characteristic of the ancien régime and introduce certain economic reforms. After his death, which some saw as a forewarning of what would happen when Franco disappeared, the crisis of the ancien régime - according to this reactionary view of our history - gave way to a chaotic nineteenth century of interminable fratricidal fights with no strong power capable of containing them, an image of the imminent disaster foreseen by those who supported the dictatorship at all costs. Those who opposed the regime, in contrast within a very broad ideological spectrum, resisted the image of a Spain historically incapable of freedom and democracy and the idea of a Spanish character inherently opposed to the modern values prevailing in Europe.

It is not a question here of analysing in detail how the traditional view of the history of Spain lost credibility and the capacity for political legitimation in the final years of Franco's dictatorship. Various factors coutributed, among them (a) the social effects of the accelerated industrialization and urbanization of the 1960s; (b) the changes that took place within the Catholic Church as a result of the Second Vatican Council; (c) the opening up to Europe that the dictatorship allowed with a view to its own perpetuation; (d) the work of a generation of new historians in Spain who undertook the task of demolishing the official orthodoxy and provided a totally different interpretation, from a liberal perspective but adopting the new economic and social history that prevailed in Europe at the time; and (e) access to secondary and university education for an ever greater proportion of the population. All of these things helped to weaken a strongly ideologized representation of the past, the simple Manichean view of our history described as 'orthodox' which, during much of the twentieth century, shaped the mentality of a large number of Spaniards. Nowadays this view of the past is so remote and foreign that it is almost a curiosity; hence its appeal for readers or audiences when it is shown to us in books, films, or plays abont those times. ${ }^{19}$ However, mentalities and attitudes 
shaped by this 'orthodox' view of the history of Spain are still much more prevalent in Spain than is generally believed.

As society became industrialized during the 1960s and an increasing number of young people gained access to secondary and higher education in Spain, history began to develop as a discipline in our universities, as had happened in other nearby countries long before. At the time, during the 1960 s and early $1970 \mathrm{~s}$, that is to say, at the height of the struggle against the dictatorship, that development did not exclude political commitment on the part of some historians. A fair number of them made this quite clear without there being any effect on the quality of the research that they conducted. Thanks to the impressive advance that took place in historical research during those two decades, it was possible to write the history of Spain from a perspective previously unknown and in a totally new way, less national and Spanish-centred, broader and more varied than had been imagined by classical liberal progressivism, and without the old organicist essentialism that had previously permeated the liberal view of the past."

The history subsequently produced in Spain took its place fully within the framework of renovation, sharing its multiplication of subjects of investigation, exploration of new sources, and use of new methods which in general terms led to a division of historiography into separate subdisciplines. The absence of great debates was the most striking feature in the case of Spain, accompanied by an accumulation of publications about the most diverse topics but without major works of synthesis such as those that had appeared at the beginning of the process of transformation. The new 'state of autonomies' favonred a separate history for each of the regions or nationalities that constituted Spain. For these and other reasons, the victory of democracy did not resolve the old conflict between the two nationalist ideologies and their respective views of the past in favour of the constitution of a single tradition of Spanish national memory/history. On the contrary, democracy made the disagreement even plainer.

Nevertheless, in a political context that changed radically as the transition to democracy took place, general views about the history of Spain underwent very significant modifications. In the early stages of the historiographic renovation, during the $1950 \mathrm{~s}$ and $1960 \mathrm{~s}$, the period that aroused the interest of historians was the time of transition from the ancien régime to modern contemporary society. At the same time, those who were fond of the medieval era or felt nostalgia for imperial Spain received the criticism of unofficial historiography, which ultimately transmitted an image of a history of Spain little different from that of Europe. ${ }^{21}$ Comparison with what was considered characteristic of the recent history of the democratic countries of the West did, however, reveal one feature specific to the development of Spain: the lack of dynamism in everything connected 
with social change. There had been no revolution of an intensity similar to that of the one that took place in France or other parts of Europe but instead a change of a political nature in a timidly liberal direction. The ultimate reason, it was thought then, was the country's economic backwardness and the absence of a middle class that was a natural consequence of that backwardness. By contrast with the more advanced countries of Europe, which experienced industrialization and the rise of an enterprising middle class, the Spain of the nineteenth century was characterized by the dominion of the old nobility and by a society and a dual economy in which sector and class features of an incomplete transition coexisted. The economic, political, and ideological weakness of the middle classes contrasted with the prestige and social power of blue-blooded aristocrats, large landowners, and leaders in the area of finance. The oligarchical power bloc that was created in the nineteenth century, after a liberal revolution that had left intact the economic foundations of the power of the old aristocracy, had thus proved to be a hindrance to economic development and evolution towards democracy.

Onto this image, which had many points in common with liheral historiography prior to the victory of Franco's dictatorship, two kinds of influences were superimposed in the 1970s during the transition from dictatorship to democracy - influences that in the end modified it without going so far as to question it. The first was explicitly Marxist in orientation, but it would be false to attribute to it the economicism and dogmatism of the political ideology that inspired it. Although there was and still is that kind of Marxism in Spanish historiography, one of the few debates to have attained a certain importance in Spain - whether there had been a 'middleclass revolution' during the nineteenth century - revealed not one but several ways of conceiving Marxism to explain the history of Spain, some of which were so 'heterodox' that they anticipated conclusions about the revolutionary process later judged to be 'revisionist' in the rest of Europe. The second influence, evident since the $1970 \mathrm{~s}$, came from the 'new economic history' and the 'new political history' that began to develop as an alternative to the influence of Marxism. Both initially put the accent on the obstacles to modernization in the course of the nineteenth and twentieth centuries.

\section{POLITICS AND HISTORY IN THE $1990 \mathrm{~s}$}

Gradually, what bad been a view of history dominated by the idea of Spain's economic and political backwardness acquired a completely different significance. During most of the twentieth century the awareness of this backwardness by comparison with the development of the other democratic 
states of Western Europe had led to an emphasis on two disasters, the loss of the last remains of the American empire in 1898 and the Civil War of 1936-39, which brought out the magnitude of the catastrophe and 'Spain's failure'. For a long time these two events created a sense of shock in the historical and political consciousness of Spaniards. If only because of the lack of a democratic regime, the political situation in the final period of the dictatorship and the beginning of the negotiated transition seemed to justify the hypercritical attitude of historians towards our past. Once democracy began to consolidate, however, a different image of the history of Spain began to win supporters. This image increasingly emphasized its similarity to the path followed by the more advanced countries in Europe and played down the importance of the 'failures' mentioned. In the past decade a good many historians have gradually begun to question the classic theses of progressive historiography (liberal-nationalist, either economic and social or Marxist-influenced) and instead to stress the image of a 'normal' historical development that could not be perceived until now, either inside or outside the country, for fundamentally ideological reasons."2

The fact that the commemorations enthusiastically supported by the governments of one political tendency or another have openly profited from this new paradigm which insists on the normality of our history should nevertheless have put the revisionist historians - so critical of the ideologies of the past - on their guard. The first of the commemorations that clearly drew political advantage from the results of the current revisionism was the one that took place in 1988, on the occasion of the bicentenary of the death of Charles III. Both the monarchy and the enlightened ministers who governed in that period with the monarchy's consent were presented as agents of the modernization of the country considerably before the outbreak of the French Revolution. They thus hecame an encouraging antecedent for the current democratic monarchy of King Juan Carlos I and the third course followed by the Socialist government, showing its equidistance from the old revolutionary aspirations of the classical left and the extreme conservatism of the right that has almost always governed Spain. As a timely complement, in 1992 the quincentenary of the 'discovery' of America brought, in the words of the historian José María Jover, 'a kind of veneer of universality enhancing the recent glad tidings that henceforth we were to be Europeans and that the years of isolation after the Civil War were gone for good'. ${ }^{23}$ Very shortly before, the Socialist government - an enthusiastic promoter of both commemorations - had succeeded in making Spain a full member of North Atlantic Treaty Organization, going against what had previously been the political posture of the party that sustained it.

In the final years of the Socialist period, bowever, there was a surprising change. Suddenly a mood of crisis and mistrust set in, with a great wave of 
accusations of corruption involving people close to Felipe González's government. This mood placed a question mark over the optimistic image of Spain's historical normality, and there was a revival of the old doomladen view of a corrupt Spain in which, under the cloak of politics, caciques and clienteles proliferated. The economic and financial scandals and the discovery of the political conspiracy of the GAL (Grupos Antiterroristas de Liberación) (an antiterrorist group that had exercised violence against the circles of the Basque separatist ETA with the complicity even of certain officials of the Ministry of the Interior) indicated the inheritance of a system that had survived from the dictatorship as a result of concessions to the past made during the transition.

In this context, in 1994 the best-selling history book Breve historia de España, by Fernando García de Cortázar and José Manuel González Vesga, put forward the idea of an 'unfinished Spain', constantly passing through areas of light and shade along its path. After experiencing an exemplary transition to democracy during the governments of Adolfo Suárez and the first Socialist era, Spain was by then in full recession, with a government that was exercising a monopoly of control of public institutions or acting as a 'front for the phenomena of corruption that mark the end of the third Socialist legislature', 'an industry dismantled by competition from European products, a disoriented agriculture and the unstoppable growth of unemployment', 'a materialistic society devoid of utopias' and 'the radicalization of the nationalist movements' ${ }^{24}$

This panorama, which suddenly had become so contrary to the exaggerated optimism of a few years earlier, was described in such apocalyptic tones that it was possible to see through it to the political purpose of the accusation. In addition to the discrediting of Felipe González, who had headed the government for too long and was by then suspected of seeking to perpetuate himself at the cost of Spain's interests, democracy was identified with an alternation of power in favour of a party - the Popular Party - that came from the traditional right and needed to occupy the political centre, until then in the hands of the Socialists, in order to win the election. While the Socialists remained immersed in impotence, incapable of cleansing their image by means of a self-criticism that might restore their credibility and bring about the replacement of their leaders, the Popular Party put together a skilful strategy that brought it to power in 1996.

After the change of government, with the same speed as before but this time in the opposite direction, the doom-laden tones were suspiciously replaced by a view that revived the encouraging normality of a historical course about to culminate in Spain's full integration into the new united Europe. The use of historiographic revisionism has been evident in the anniversaries enthusiastically supported by the Popular Party government. 
Thus the 'disaster' of a century ago (the 'crisis of 1898') ended up being presented as an exaggeration on the part of intellectuals steeped in radicalism and demagoguery, unable to understand the extent to which, thanks to the efforts of the Liberal politicians of the time, Spain was then following the course of economic modernization and politics pursued by countries of the Western world. ${ }^{25}$ Far from being a historical rarity in our country, liberalism had a long tradition of modest successes back at least as far as the Restoration years under Cánovas. At the same time, Cánovas was rehabilitated as a true statesman who had been attacked by extremists of both tendencies. His regime, contrary to progressive or Marxist historiography, was declared to have had very positive effects. It had been able to put a stop to militarism for a long period, establish a system for the enjoyment of rights and freedoms equivalent to those of the most advanced countries in Europe, and create a climate of social peace that made possible the development of the Spanish economy. In the context of this kind of historiographic revisionism, highly favourable to the achievements of the Restoration regime but as exaggeratedly partial as the earlier scathing criticism, it is not surprising that the Popular Party took advantage of Cánovas's centenary to convert him into the great precursor of their policies. ${ }^{26}$ It had been much harder for the Conservative leader Manuel Fraga Iribarne when he championed Cánovas, at a time when revisionist history did not yet exist and the predominant view was of a backward Spain in the hands of oligarchs and caciques.

Finally, the pretext of the quarter-centenary of the death of Philip II offered a further opportunity to use history for political ends, with a Spanish nationalist smugness that succeeded in wounding the sensibilities of Portuguese neighbours at Expo 98 in Lisbon. The supposed universality of which Jover spoke to us in connection with the quincentenary of the 'discovery' of America was now reinforced by a staging interested only in highlighting the splendour of a reign full of brilliance in the spheres of art and culture. ${ }^{27}$ Seen in this light, Philip II was a prince of the Renaissance willing to govern a great 'confederation of territories' with wisdom and humanity - a king, according to the historian Henry Kamen, who pursued 'universal pleasures and interests' although 'imbued with a deep religiosity like most rulers of the time'.$^{28}$ The book by this scholar of Spanish affairs, Philip of Spain, has also been a best-seller, ${ }^{29}$ and, as Antonio Elorza rightly foresaw, it set the pattern for 'the commemorative image of the great king who inspired the name of the current heir to the Spanish throne'. ${ }^{\text {no }}$ This desire on the part of our current rulers to display the most brilliant, normalized, acceptable part of our past - art, science, universalism - from a European perspective, setting aside social manifestations that have become less presentable and the conflicts that formerly marked us, now appears with 
very suspicious self-satisfied reiteration. This happened once again in connection with the crisis of $1898^{31}$ and has been repeated in exhibitions such as the one recently organized by the Valencian Autonomous Government and the Archbishopric of Valencia on 'the important part played by the Church in the historical development of the Valencian Community and the wealth of an artistic and cultural legacy that is to a large extent unknown', ${ }^{32}$ The title of the exhibition, 'The Light of Images', is highly illustrative; the darker areas, evidently, do not deserve to be remembered.

The current historiographic revisionism also has other political uses that are more worrying because of the intention that they reveal. Until very recently - in due correspondence with the optimism promoted by the current conjuncture of democratic stability and economic success, which, as we have seen, has modified our image of the past and lifted it out of its obsession with backwardness and decline - a veil of oblivion and caution had been drawn over our more recent history. Timely reference to this is made in Paloma Aguilar Fernández's book Memoria y olvido de la guerra civil española, ${ }^{13}$ and this situation, which, as we have seen, at the time worked in favour of the reconciliation of Spaniards, could now have effects that might run counter to the establishment of democratic values. The demythologizing of the Republican side that is beginning to appear in historical research is clearly not the problem. Part of the work of historians constantly to revise what has been written about the past and to highlight any kind of ideological influence on the different ways of studying a historical event. The problem is the onesided, tendentious way in which the results of this research are being presented to a hroad public and the unusual interest aroused by these studies, especially when they are concerned with combating the image of those who fought on the Republican side during the 1936-39 war (this is the case with the International Brigades, to give one example) or covertly seeking a partial rehabilitation of Franco's regime and of his person - in the final analysis, a pioneer in the victorious struggle against revolutionary socialism, as subsequently one of his admirers in Chile, General Augusto Pinochet, would also appear to have been. The defeat of communism and the success of modernization in our country thus seem to be connected with a 'really not very fascist' regime, supposedly with an authoritarian ideology that was not particularly firm and consequently was capable of admitting internal dissidence which later made possible the pact leading to democracy. Such a falsification of history, as some historians have recently charged, overlooks the degree to whicb Franco's dictatorship was radically antiliberal, the extent to which it repressed democrats of all kinds, and the way in which, until the very end, it hung on to its desire to be perpetuated, something that proved impossible as Spanish society developed and became integrated into Europe. 
Finally, in contrast to the situation during the years of struggle against the dictatorship, the idea of highlighting the diverse, plural reality of our country and at the same time pointing to its a common history seems to have little support. Works of synthesis offering a history of the 'autonomous communities' provoke an angry reaction from advocates of a single history of the 'Spanish nation', who see the former approach as propitiating nationalist separatisms or becoming locked in localism. The debate has extended into the area of the education of children and adolescents and the question of what kinds of history should be taught nowadays. ${ }^{34}$ Criticizing and demythologizing any kind of use of history for nationalist ends does not seem to have been defended consistently by a good many of the participants in this debate. This, at least, is the situation when the very individuals who present timely, well grounded criticism of Spanish historiographic nationalism nevertheless defend a nationalist history in the case of Catalonia (or the Catalan Lands), Euskal Herria, or Galicia. And the same could be said of those who are in favour of dismantling myths about origins and nationalist manipulations of history when it is a question of these other nationalisms but who are none too willing to detach themselves from the idea of a Spanish national development basically identified with the history of the predominance of one society, one language and one culture (Castile). Three examples may serve to illustrate this: the controversy in Catalonia about the development of its historiography, ${ }^{35}$ the recent debate about the teaching of the humanities already mentioned (and the conception of the current Ministry of Culture and Education, the historians who have advised it, and the intellectuals who have applauded it, not exactly of right-wing origin), and the recent award of a national essay prize to the collective book El ser de España. ${ }^{3 t}$ No doubt we should connect all this with the current debate about whether there is a need to reform the democratic Constitution of 1978 in the context of the demands for a greater degree of selfgovernment put forward by peripheral nationalisms.

As stated at the outset, history has an important political part to play in the current situation. The special feature of Spain among the Mediterranean countries in connection with the political uses of the past is apparent, broadly speaking, in a developmeut bounded by two fin-de-siecle crises of very different kinds. A hundred years ago, the disaster represented by the loss of the last remnants of the colonial empire was evident to all. From that crisis a kind of 'regenerationist' nationalism emerged that advocated replacing the old state of notables or oligarchs characteristic of a backward agrarian society with a different, more modern one supported by new social groups. The current crisis, however, must be set in a totally different social and political context. Its cause is not industrialization or any colonial disaster or general sense of backwardness in relation to other countries. The statement 'Spain is 
doing well', made by the Prime Minister, José María Aznar, immediately after coming to power in 1996, reveals the inordinate optimism that invades the country now, contrasting with the equally exaggerated pessimism of a century ago. If there is a crisis in Spain today it is certainly for other reasons, especially the awareness that the globalization to which Spain is tending is numbering the days of the nation-state just as it is in other parts of Europe.

In another context, therefore, very different from that of a century ago, in Spain too the various groups that dispute hegemony have linked their respective political projects to conflicting views of the past. At first sight it would seem that we are faced with a new edition of the old, interminable debate about the 'problem of Spain', ${ }^{37}$ first put forward during the crisis at the end of the nineteenth century. However, the area of the debate is utterly different. Whereas 100 years ago the 'problem of Spain' arose from an awareness that its history was one that included numerous failures and an extraordinary decline, now the immediate future of a united Europe, in which for some years Spain has been playing a leading role, is tending to erase differences and highlight similarities in a development in which only successes are of interest. In this new European context, those who consider Spain's existence as a nation unchallengeable are advocates of a history that reinforces the collective feeling of belonging to that incontrovertible reality'. For those who think that Spain as a collective entity must gradually give way to other identities, in contrast, recourse to history serves to legitimize other political options that may favour the maximum autonomy or even independence of hitherto stateless nations in the not too distant future.

However, anyone who thinks that the current debate will in future take place on the same intellectual horizon as in the past is mistaken. Although a revival of conflict between nationalist ideologies appealing to history remains very likely, the fact is that in the new era that we are entering the crisis of national identities classically conceived - with or without a state - is becoming increasingly apparent. Internal cultural homogenization and the exclusion of those who do not share the features of an identity that, after all, can always be reinvented are becoming increasingly meaningless. Our world is tending towards multiculturalism, and the coexistence and superimposition of multifarious identities capable of resolving conflicts by means of dialogue and communication make it necessary to think about a new political use of history. This new use will be sorely needed to provide an impulse for the future development of societies that will increasingly be experiencing both globalization and internal differentiation. If historians take refuge in scientific asepsis at this crucial moment, others will go on using history to legitimize old powers and impose identities that will perpetuate the current conflicts. 


\section{NOTES}

1. See, for example, some of the more important controversies included in H.-U. Wehler, Politik in der Geschichte (Munich, 1998).

2. Referring only to recent publications, see Afers, 25 (1996); Ayer, 33 (1999); and the review of some of the more outstanding books and articles in S. Juliá, 'Un fascismo bajo Palio, en uniforme nilitar', Babelia-El País, 349 (18 July 1998). Reference to the polemic unleashed in Italy by the attempt by S. Romano and I. Montanelli to revise the figure of Franco and his political regime is made by M.A. Macciocchi in 'Franco y los revisionistas', El País (26 June 1998).

3. Ayer, 15 (1994); J. Tusell and Á. Soto (eds.), Historia de la transición 1975-1986 (Madrid, 1996).

4. See the polemic aroused by the article by J. Marías, 'El artículo más iluso', El País \{26 June 1999).

5. In barely two months at the end of 1997, according to the data of the Ministry of Education, 650 essays and elitorials appeared in the Spanish press.

6. I. Peiró, Los gaardianes de la historia (Saragossa, 1995).

7. Pierre Nora (ed.), Les lieitx de mémoire, 3 Vols. (Paris, 1997). For its reception in Spain, see Ayer, 32 (1998).

8. See the references in J. Cuesta, 'Memoria e historia: Un estado de la cuestión', Ayer, 23 (1998), pp.203-46.

9. F. García de Cortázar and J.M. González Vesgá, Breve historia de España (Madrid, 1994); J. Tusell (ed.), Historia de España (Madrid, 1998).

10. Reference is made to this in the contributions to Aver, 30 (1998).

11. Jeffrey Olick, 'Memoria colectiva y diferenciación cronológica: Historicidad y ámbito público', Ayer, 32 (1998), pp.119-45.

12. In fact, going beyond metaphors, Spanish nationalist music is late and exceptional (Falla, Albéniz).

13. For this further problem, see the controversy between B. de Riquer and J.P. Fusi in Historia Social, 7 (1990), pp.105-35; the article by B. de Riquer, 'Naciones y regiones: Problemas en torno a la débil nacionalización del siglo XIX', included in the collection edited A. Morales Moya and M.E. de Vega, La historia contemporainea de España (Salamanca, 1996), pp.73-89; J. Álvarez Junco, 'La nación en duda', in J. Pan-Motojo (ed.), Más se perdió en Cuba: España, 1898 y la crisis fin de siglo (Madrid, 1998), pp.405-75; J.M. Fradera, Cultura nacional en tuna societat divida: Patriotisme i cultura a Catalunya (1836-1868) (Barcelona, 1992).

14. I emphasize the aspect of process to call attention to what has been written about the modern conception of history by $\mathrm{H}$. Arendt in 'Historia e inmortalidad', included in De la historia a la acción (Barcelona, 1995), pp.47-73, and R. Koselleck, Futuro pasado: Para una semántica de los tiempos históricos (Barcelona, 1993).

15. Some of the primary school textbooks that were extensively used in the 1920s are a good indication of this: the Compendio de historia de España by G.M. Bruño, the Compendio de historia de España by the Piarist priest Francisco Asensi, and others.

16. The supporting texts are from the 1940s and 1950s, focusing on the teaching of history; see the analysis by $\mathrm{R}$. Vills in La interpretación de la historia de España y sus origenes ideológicos en el bachillerato franquista (1938-1953) (Vilencia, 1984), and E. Martínez Tórtola, La enseñanza de la historia en el primer bachillerato franquista (Madrid, 1996). One of the first attempts at historical legitimation of the figure of Franco and his regime is Laureados de España, published in the 'Year of Victory' (Madrid, 1939), with contributions by, among many others, J. Penmartín, Fr. J. Pérez de Urbel, M. Machado, G. Diego, C.J. Cela, V. de la Serna, and J.I. Luca de Tena. On the historiography of the early Franco period, see the interesting work by G. Pasamar, Historiografia en la postguerra españolu: La nuptura de la tradición liberal (Saragossa, 1991). 
17. See, for example, the long list of historical novels and 'national episodes' by B. Pérez Galdós. For the Marquis of Lozoya, in La concepción romántica de la historia (Valencia, 1930), the key to the success of liberal ideology in the late nineteenth century was the cultivation of history and historical novels of higher literary quality than those of the traditionalists.

18. See especially the chapter devoted to him by C.P. Boyd in Historia Patria: Politics, History, and National Identity in Spain, 1875-1975 (Princeton, 1997), highly recommended, incidentally, on the subject that we are considering.

19. The most obvious case is the book, later made into a play, by A. Sopeña Monsalve, El florido pensil: Memoria de la escuela nacionalcatólica (Barcelona, 1994).

20. The development of Spanish historiography during the 1950s, 1960s and early 1970s can be seen in the overall appraisal made in 1974 by J.M. Jover, recently republished with the title 'El siglo XIX en la historiografía española de la época de Franco' in his Historiadores españoles de nuestro siglo (Madirid, 1999).

21. Reference must be made to the Catalan historian Jaume Vicens Vives, one of the most outstanding figures in the historiographical renovation in Spain. See the book by J.M. Muñoz Lloret, Jaume Vicens $i$ Vives: Una biografia intellectual (Barcelona, 1997).

22. Exponents of this are the numerous works mentioned by $\mathrm{S}$. Julia in his article 'Anomalia, dolor y fracaso de España', Claves de Razón Práctica, 66 (1996), pp.10-21. Comparison with an earlier article of his, 'Transiciones a la democracia', Sistema, 84 (1988), pp.25-40, shows the change that has taken place in him in the past ten years. Juliá is, however, one of the historians who have fought most resolutely in the media against viewing Spain as a country with a normal historical development without taking into account other much less comparable aspects of our past. The book by J.P. Fusi and J. Palafox, España 1808-1896: El desafio de la modernidad (Madrid, 1997), one of the best-sellers of recent years, is possibly the work most representative of the revisionism that radically questions the exceptional nature of Spain and abandons the 'myth of failure'. See C. Powell's interview with J.P. Fusi at the time of the book's publication in the literary supplement of the newspaper $A B C$ (28 Nov. 1997).

23. J.M. Jover, 'El centenario que viene', El País (10 Dec. 1996), p.13

24. García de Cortázar and Gonzílez Vesga, Breve historia de España, Ch.l, pp.53-7.

25. This is the interpretation offered by J.M. Marco in La libertad traicionada (Barcelona, 1997), a book that made a particular impact on the public after being presented by the prime minister, José María Aznar.

26. An option that can be understood only if one views the Cánovas period as favourably as does recent historiography but proves curious and significant in the light of the timely comment made by A. Elorza in 'Una pasión excesiva', El País (24 Aug. 1997): 'However much the pill is sugared, the place of Cánovas in history is closer to authoritarian conservatistn than modernizing liberalism'. In the same context of criticism of the recovery of Cánovas by the Spanish right, see the article by S. Juliá, 'Gran estadista, ruina de Estado', El País (20 Aug. 1997).

27. See the splendid catalogue for the exhibition Felipe II, un monarca y su época: Un principe del renacimiento, presented at the Museo Nacional del Prado in Madrid from 13 Oct. 1998 to 10 Jan. 1999.

28. Quoted literally by the journalist M.Á. Villena in El País (5 Nov. 1998) in a debate that elicited considerable response in the media, with the participation of Geoffrey Parker, author of The Grand Strategy of Philip II (New Haven, 1998). For Parker, an authoritarian nature and religious fundamentalism are two notable characteristics of the Spanish monarch's personality, which is a long way, therefore, from the positive view that has predominated in the official commemorative acts.

29. Published in Spanish as Felipe de España (Madrid, 1997), it reached a third impression between May and August of that year, something quite extraordinary for that kind of book in Spain. 
30. A. Elorza, 'Crisis del imperio', El País (17 Jan. 1998).

31. The exhibition 'España fin de siglo 1898', which opened at the former Museo Español de Arte Contemporáneo on 9 Jan. 1998, presenting a mixture of 'erudition and beauty', as reported in the account that appeared in the newspapers, and delving into the other side of 1898: not the colonial disaster and the accusations made by the writers of the generation of ' 98 but the daily reality and everyday life, the economic and cultural continuity despite the loss of the colonies, and the scientific advances and improvements in health. The exhibition 'Un siglo de ciencia en España', which opened at the Residencia de Estudiantes on 23 Dec. 1998, concluded the events that reviewed the centenary of 1898 .

32. Quoted from the guide to the exhibition 'La luz de las imágenes', published by the Generalitat Valenciana. The exhibition was a considerable public success, so much so that the organizers were obliged to extend it.

33. P. Aguilar, Memoria y olvido de la gnerra civil española (1936-1939) (Madrid, 1996).

34. I have referred to this in 'La historia en el debate político sobre la enseñanza de las humanidades', Ayer, 30 (1998), pp.63-100.

35. Partially included in the book by A. Balcells, La història de Catalumya a debat: Els textos d'una polèmica (Barcelona, 1994).

36. Real Academia de la Historia, España: Reftexiones sobre el ser de España (Madrid, 1997). An intelligent critique of the political background was made by J.S. Pérez Garzón, 'Españoleando con la historia de la Academia', in El País, 9 Dec. 1998.

37. See J. Varela, La novela de España: Los intelectuales y al problema español (Madrid, 1999). 


\section{DOURNAL OFFPRINT}
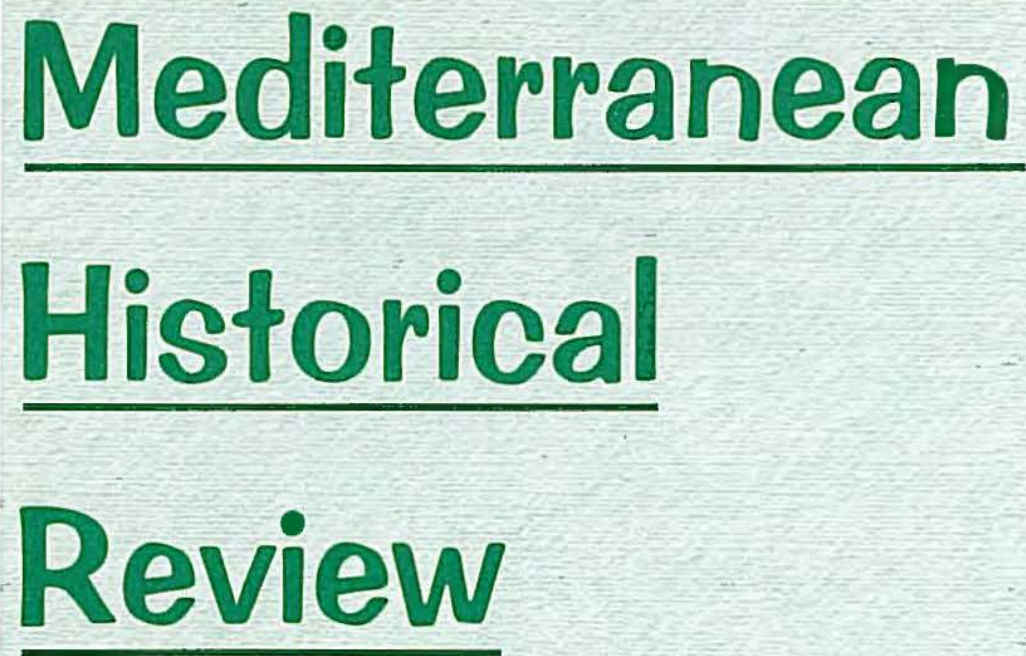

\section{A FRANK CASS JOURNAL}

ISSN 0951-8967

UK and RoW: Frank Cass, Crown House, 47 Chase Side,

London N74 5BP, England

Tel: $+44(0) 2089202100$ Fax: $+44(0) 2084478548$

Email: inls@frankcass.com

North America: 5824 NE Hassalo Street, Portland,

OR 972133644 , USA

Tel: 8009446190 Fax: 5032808832 Email: inls@isbs.com 


\title{
MEDITERRANEAN HISTORICAL REVIEW
}

\section{Political Uses of the Past}

The Recent Mediterranean Experience

\author{
Editors \\ JACQUES REVEL \\ GIOVANNI LEVI
}

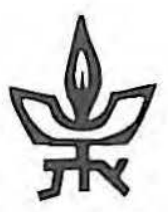

$\frac{\text { TEL AVIV UNIVERSITY }}{\text { A FRANK CASS JOURNAL }}$ 